\title{
Responses of Insect Pests and Plant Diseases to Changing and Variable Climate: A Review
}

\author{
Rumbidzai D. Katsaruware-Chapoto ${ }^{1,2}$, Paramu L. Mafongoya ${ }^{1}$ \& Augustine Gubba ${ }^{1}$ \\ 1 School of Agricultural, Earth and Environmental Sciences, University of KwaZulu-Natal, Scottsville, \\ Pietermaritzburg, South Africa \\ ${ }^{2}$ Faculty of Agriculture, Zimbabwe Open University, Mashonaland West Region, Chinhoyi, Zimbabwe \\ Correspondence: Rumbidzai D. Katsaruware-Chapoto, Faculty of Agriculture, Zimbabwe Open University, \\ Mashonaland West Region, P.O. Box 285, Chinhoyi, Zimbabwe. Tel: 263-733-831-052. E-mail: \\ rdkatsaruware@gmail.com
}

Received: February 19, $2017 \quad$ Accepted: April 5, $2017 \quad$ Online Published: November 15, 2017

doi:10.5539/jas.v9n12p160 URL: https://doi.org/10.5539/jas.v9n12p160

The research is financed by National Research Foundation of South Africa (NRF-SA).

\begin{abstract}
Natural and anthropogenic factors have resulted in altered environmental conditions that influence changes in abundance and diversity of insect pests. Global climate change projections focus on crop yields and adaptation strategies to declining yields and ignore the likely impact of a changing climate on insect pests and plant diseases. In this research paper, we review the effects of climate variables namely temperature, carbon dioxide $\left(\mathrm{CO}_{2}\right)$, precipitation and extreme weather events on insect pests and plant diseases incidence. Elevated temperatures, $\mathrm{CO}_{2}$ and extreme weather events have been shown to alter the distribution, reproductive potential, the incidence and abundance of plant insects and diseases in temperate regions because of the dependence of insects and diseases on environmental conditions. There is limited information on the influence of temperature and carbon dioxide as well as their interaction on the incidence and severity of insect pests, bacterial and viral diseases in the tropical regions. Information on the influence of altered precipitation patterns is also limited but could be of importance in insect distribution studies in a changing climate. Some tropical insects pests are most likely to suffer from extreme heat, resulting in death and hence pest extinction. Future research should focus on the interaction of elevated temperature and $\mathrm{CO}_{2}$, determine the influence of supra optimal summer temperatures, temperature variability, precipitation variability and the corresponding viral and bacterial diseases.
\end{abstract}

Keywords: changing climate, elevated temperature, insects, pathogens

\section{Introduction}

Human activities and natural factors have led to rapid and extreme increases in atmospheric gases such as carbon dioxide, methane, chlorofluorocarbons and other greenhouse gases (IPCC, 2013). The increases in greenhouse gases have resulted in a number of observable climatic changes such as elevated temperatures (Jamieson et al., 2012), increased occurrence and severity of extreme weather events such as droughts, floods (Mearns et al., 2013) and intense tropical cyclones (Nissen et al., 2014). According to the Intergovernmental Panel on Climate Change (IPCC, 2007), the world's average temperature has increased by $0.07^{\circ} \mathrm{C}$ for every decade in the $20^{\text {th }}$ century. The first decade of the $21^{\text {st }}$ century, however, has been the warmest period on record (AMCEN, 2011). There is also evidence that the rate of climate warming is increasing (IPCC, 2013) and the global climate change models predict a continued increase of atmospheric temperatures beyond the $21^{\text {st }}$ century, even if the amount of gaseous emissions are to be reduced (Burrows et al., 2014; IPCC, 2013). On the other hand, $\mathrm{CO}_{2}$ levels have increased from $280 \mathrm{ppm}$ in 1750 to $368 \mathrm{ppm}$ in the year 2000 (Watson, 2001). The levels of $\mathrm{CO}_{2}$ are expected to increase to 1000 ppm by the end of the 21 st century (Sanderson et al., 2011).

The increase in frequency and intensity of extreme weather events, changes in moisture conditions, temperature rises and elevated carbon dioxide concentrations are expected to magnify pest pressure on agricultural systems through various ways (Johnson et al., 2013). Insect pests are likely to respond through range expansion of the existing insect pests, invasion by new insect pests and accelerated insect pest development (Parvatha, 2015). 
There is also a likely disruption of temporal and spatial synchronization of insect pests, diseases and beneficial insects which will increase risks of insect pest outbreaks (Jaworski \& Hilszczanski, 2013). Due to complex and highly variable responses of pests and their hosts to multiple and interactive shifts in environmental conditions, it is difficult to accurately quantify the potential impacts of climate change on pests.

The changes in environmental conditions include elevated $\mathrm{CO}_{2}$, changes in temperature and relative humidity, cloudiness, shifts in rainfall patterns, wind patterns, land cover and land use changes. Extreme weather events (dry and wet conditions) are key factors in triggering endemic and emerging insect pest outbreaks (Anderson et al., 2004). Increased frequency of extreme weather which is expected to occur with climate change and variability is set to increase the agricultural pest burden. Dry periods tend to increase insect and viral outbreaks, while wet periods are likely to encourage fungal and bacterial diseases and indirectly affect population dynamics of insect pests. Areas of concern for managing pests under climate change include pest range expansions, increased weed competitiveness, effects of drought stress on pests and reduced effectiveness of integrated pest management.

In a changing climate, insect pests and plant diseases present a major threat to global crop production and food security (Chakraborty \& Newton, 2011). However, many assessments of the effect of climate change on agriculture have focused on adaptation measures (Parvatha, 2015) and the potential impacts of climate change on crop yields (Moyo et al., 2012). Other yield limiting factors such as insect pests and crop diseases have not been taken into consideration in most of these assessments (Selvaraj \& Pandiara, 2013). There is, therefore, a risk that future crop yields might be overestimated if the impacts of insect pests and plant disease epidemics are not taken into consideration (West et al., 2015). In the tropical areas, there have been few studies on the effect of global warming on insect pests of agricultural crops (Perkins et al., 2011) with the exception of the coffee berry borer (Jaramillo et al., 2009) and the potato tuber moth (Kroschel et al., 2013) and yet tropical insects are at a greater risk from climate change as they inhabit hot environments (Zeh et al., 2012). This review will, therefore, examine the impact of each of the climate change variable in more detail.

\section{The Impact of Elevated Temperature on the Biology of Insect Pest and Diseases}

Elevated temperature is one of the most important drivers of climate change that directly affect the timing of seasonal biological events of the majority of the arthropods, particularly insects (Altermatti, 2012; Miller-Rushing et al., 2010; Savopoulou-Soultani, 2012; William et al., 2015). The majority of insect pests are cold-blooded invertebrates and, therefore, do not use their metabolism to maintain their body temperature (Petzolet \& Seaman, 2010), but depend on surrounding temperatures for all their biological activities (Jaworski \& Hilszczanski, 2013). Increases in the ambient temperatures may result in various changes such as a shift in geographical distribution, increased overwintering, extension of the insect development season, increase in the number of insect generations which result in changes in population growth rates and also increased risk of invasion by migrant pests (Ahanger et al., 2013).

The increased rates of insect development are achieved through a reduction in the length of the biological life cycle of insects from the egg, larval, pupal and the adult stages (Newton et al., 2011; Seiter \& Kingslover, 2013). Effect of elevated temperature on the length of larval development has been observed under laboratory conditions for two species of native foliophages, the nun moth, Lymantria monacha (L.) which attack mainly corniferous trees and the gypsy moth Lymantria dispar (L.) which attack oak trees, shrubs and apples trees in Asia (Karolewski et al., 2007). For both insect species, increase in temperature from $15{ }^{\circ} \mathrm{C}, 20^{\circ} \mathrm{C}$ and $25^{\circ} \mathrm{C}$ had an influence on reducing the length of the life cycle, from egg phase to the pupal phase (Jaworski \& Hilszezenski, 2013). In the majority of the studies, it has been estimated that with a $2{ }^{\circ} \mathrm{C}$ temperature increase, insects might experience one to five additional life cycles per season and produce more eggs (Yamamura \& Kiritani, 1998). In a study that evaluated the biology of leaf hopper (Nilavarpatha lugens) under a $3{ }^{\circ} \mathrm{C}$ temperature increase in Asia, the short winged females deposited $48.1 \%$ more eggs in elevated temperature treatments than under ambient temperature treatments (Shi et al., 2014). In a similar study, adults that were exposed to elevated temperature treatments emerged on average 1.3 days earlier than those that were exposed to ambient temperatures (Shi et al., 2014). In East Africa, in a study with the Coffee berry borer (Hypothenemus hampei), using the CLIMEX model, a $2{ }^{\circ} \mathrm{C}$ increase in temperature from the ambient temperature was predicted to increase the number of generations as well as the damage by the Coffee berry borer (Jaramillo et al., 2011). As a result of increased warming, earlier emergence and development of these insects is therefore anticipated (Jamieson et al., 2012) with the possibility of causing intense insect pest problems in the future. This, in turn may lead to insect population increases (Flower et al., 2014; Jamieson et al., 2012). 
The warmer environmental conditions will also allow insect pests to disperse to new regions from which they were previously excluded because of low winter temperatures (Parvatha, 2015). The insects shift their geographical location to higher-latitudes or higher elevation areas (Sharma et al., 2013). The migration of insects such as Helicoverpa armigera, a major pest of cotton, pulses and vegetables in North India is predicted to increase with increased warming from the southern parts of India (Sharma et al., 2010). This movement cause insects to adapt to new host plants thereby altering the structure, diversity and functioning of ecosystems (IPCC, 2007) and increasing the host range of insect pests (Jaworski \& Hilszezenski, 2013). In a study that was conducted in Zimbabwe, using the Generalized Linear Models (GLM) on coffee white stem borer (Monochamus leuconotus $\mathrm{P}$.), it was predicted that the area suitable for the insect will increase in Chimanimani district by up to $200 \%$ by 2080 (Kutywayo et al., 2013). This suggests that some geographical areas that are too cold or unsuitable for certain insect species under the current climate scenario may become susceptible to insect pests under future climates. However, a contraction on population of vertebrate pests in the temperate regions (Bellard et al., 2002) can also occur on insect pests that require colder conditions such as the armyworms (Mitrovski et al., 2008; Terblanche et al., 2008). This implies that in the temperate areas, further increases in temperature will result in the shrinking of insect pest population.

Increase in the minimum temperatures increase survival of insect pests during the winter season season (Fand et al., 2012). In India an increase in winter temperature by $1-5{ }^{\circ} \mathrm{C}$ promote insect development at times of year when insect development would normally be suspended (Sharma et al., 2010; Sharma et al., 2013). This leads to earlier insect activity in spring and late appearance of insects in autumn, for the majority of temperate insect species (Fand et al., 2012; Jong et al., 2011). This increase in mean temperatures in a climate change scenario would increase insect survival due to low winter mortality and, hence, increased population growth (Sharma et al., 2010). In frost sensitive areas, increased warming results in a reduction in mortality events caused by chilling or freezing injury (Khaliq, 2014). This means that there will be an increase in insect survival in the areas that were previously unsuitable for insect pest development as a result of low winter temperatures.

Insects can change their behaviour as a result of a change in temperature conditions (G. Ma \& C. S. Ma, 2012a). Movement of insect pests from one part of the plant to the other is also a response to warmer leaf temperatures (G. Ma \& C. S. Ma, 2012b). In a study in India, heat stress forced movement of insect pests (Metopolophium dirhodum and Aphis gosspii) from the tender upper leaves to the bottom older leaves (Liu et al., 2000) where cool microhabitats in the lower leaves prevent heat injury to the aphids (G. Ma \& C. S. Ma, 2012b). This implies that there is a possibility for insect pests to be constantly moving down the lower plant leaves in response to high temperatures as a way of escaping heat stress and, hence, a reduction in the time they spend feeding on the crops.

Extreme temperatures in the tropical areas can lead to heat induced coma and insect death (G. Ma \& C. S. Ma, 2012a). In a study with Nilaparvatha lugens (a tropical rice pest) in India, the results of the effect of temperature on the insect indicated that the first instar nymphs became immobilized by heat stress at around $30{ }^{\circ} \mathrm{C}$ and among the more heat tolerant adult stage, no insects were capable of a coordinated movement when the temperature was increased to $38^{\circ} \mathrm{C}$. The insect did not recover after entry into heat coma, at temperatures around $38^{\circ} \mathrm{C}$ for the nymphal stages and $42-43{ }^{\circ} \mathrm{C}$ for the adult stages (Piyaphongkul et al., 2012). These results suggest Nilaparvatha lugens can become extinct in the future in the tropical regions when temperatures continue to rise as is projected.

Plant diseases occur when there is an interaction of three factors namely, a susceptible host, a sufficiently effective pathogen inoculum and suitable environmental conditions (West et al., 2015). The incidence of vector transmitted plant viral disease is expected to increase with increasing temperatures (Robinet et al., 2011; Malmstrom et al., 2011). Increasing temperatures increases insect vector expansion, feeding activity, transmission rates and increases the potential for new insect vectors (West et al., 2015). An increase in the incidence of viral diseases is predicted to occur due to either increased winter survival of insect vectors with increasing temperatures or early spring migration of the insect vectors (Mirski et al., 2012). In some experiments, warmer winters have been associated with an increase in viruses of many crops while warmer soils affect soil-borne viruses as the insect vectors will be able to infect crops at an earlier stage of crop growth (West et al., 2015).

Temperature increases will extend the period of time that is available for fungal reproduction, dissemination and evolution (Nurhyati, 2013). Increased temperatures may increase the metabolic rates of fungal pathogens as well as the rate of infection (Thompson et al., 2010). Warmer temperatures also remove a limiting factor for plant pathogens resulting in an increase in the geographical area that is at risk of the disease due to range expansion of the pathogen (Jaworski \& Hilszczanski, 2013). Climate induced high temperatures increases the severity of fungal pathogens such as the fusarium head blight (FHB) (Chakraborty, 2011). Fusarium culmorum and 
Microdochium nivale have been the prevalent pathogens in cooler climates of Europe, but in the last decade $F$. graminearum has become the dominant species resulting in the high prevalence of FHB in the Netherlands (Waalwijk et al., 2003), England, the Wales (Jennings et al., 2004) and northern Germany (Miedaner et al., 2008), because of the higher temperature optimum of the pathogen. This implies that with increased warming, there is likelihood that the incidence of fusarium blights will increase.

In north-western plains of India, late blight of potato used to occur in mild to moderate form only once in 4 to 5 years, but more recently as a result of climate warming, it is occurring every 2 years (Luck et al., 2011). Climate warming extends the period of activity of the late blight pathogen (Luck, 2011). Hijmans (2000) has predicted that for each $1{ }^{\circ} \mathrm{C}$ warming, late blight would occur 4 to 7 days earlier, and the susceptibility period is extended by 10 to 20 days (Kaukoranta, 1996). In India, late blight now appears earlier in the northern part (November) and later in eastern parts (February) and within a higher temperature range of $14-27.5^{\circ} \mathrm{C}$ than at $10-25^{\circ} \mathrm{C}$ which used to occur in the past (Luck et al., 2011).

A change in the genetic makeup of plant pathogens is expected under increased warming conditions. There is evidence of significant changes in the genetic makeup of populations of plant pathogens Phytophthora infestans in India and Bangladesh over the past two decades, including the appearance of an A2 type, thereby increasing the frequency of late blights epidemics in India over the past 15 years (Luck et al., 2011). In India, the efficacy of metalaxyl fungicide treatments for late blight control was significantly reduced in the last few years, suggesting the possible emergence of new late blight resistant strains in west Bengal (Luck et al., 2011). This implies that there is going to be an increase in pesticide resistant pathogens strains in the future as a result of the emergence of new pathogen biotypes that emerge as a result of increased warming.

Despite an increase in the incidence of many fungal pathogens, severity of stripe rust disease is predicted to decrease during the 2050 season compared to the 2006 season (Abolmaaty et al., 2011). Research has shown that some forage species become more resistant to the rust fungi with increased temperature (Coakley et al., 1999). This is indirectly enhanced by increased lignification of the grass species under warmer atmospheric conditions (Furher, 2003) which decreases the susceptibility of the grass species to fungal attack.

There is an indication that most of the studies relating elevated temperature to insect pests and diseases in a changing climate were mainly conducted in Asian countries. There is need for research in the tropical areas such as the Southern African region or during the summer temperatures to determine the effects of elevated temperature on insect pests and diseases of tropical regions. The impact of variable temperature which also characterises climate change also needs to be explored than merely focusing on elevated temperatures. There is a need to include more bacterial and viral diseases in climate change studies in tropical regions such as Southern Africa.

\section{Effect of Elevated Carbon Dioxide on Insect Pests and Diseases}

Rising $\mathrm{CO}_{2}$ levels in a changing climate may affect the distribution, abundance and performance of insect pests (Chakraborty et al., 2008). There have been reports of increase in crop consumption by insect pests by at least $10 \%$ under elevated $\mathrm{CO}_{2}$ levels (Gonzales-Vigil et al., 2011). However, the responses of insect pests to feeding activity at elevated levels of $\mathrm{CO}_{2}$ levels vary with the feeding habit of the insect pest (Hilstrom et al., 2010). Chewing insects such as the Lepidopterans, which chew and digest the whole leaf increase the rates of feeding upon the crops as a result of reduced nitrogen to carbon content which results in compensatory feeding (Hughes \& Bazzaz, 2001). Phloem and xylem feeding insects such as the Hemipterans may be less affected by elevated $\mathrm{CO}_{2}$ levels because they feed on plant sap, which is low in defensive compounds (Furstenberg-Hagg et al., 2013). Insect pests that feed on seeds also may be less affected by increased $\mathrm{CO}_{2}$ levels because they maintain high levels of nitrogen in their reproductive system and hence have no need to acquire more nitrogen from the crops (Karowe \& Migliaccio, 2011).

High $\mathrm{CO}_{2}$ promotes foliar diseases such as rusts, powdery mildews, downey mildews, leaf spots and blights. The foliar diseases are enhanced through an increase in canopy density resulting from enhanced photosynthesis (Furher, 2003; West et al., 2015). Leaf diseases such as the leaf blotch or scald (Rhynchosporium secalis) and ramularia leaf spot (Ramularia collocygni) of barley, tan spot (Pyrenophora triticirepentis) of wheat, and alternaria dark pod spot of oil seed rape (Alternaria brassicae) are predicted to increase in severity due to an increase in epidemic cycles, greater plant biomass and denser canopies for most of the vegetative crop growth period under elevated carbon dioxide levels (West et al., 2015). Low light levels and reduced air circulation in dense crop canopies result in higher relative humidity, which promote the sporulation and growth of many plant pathogens (Eastburn et al., 2010). 
There is limited information on the direct effects of $\mathrm{CO}_{2}$ on insect pests and diseases. There is need for more research on the effect of $\mathrm{CO}_{2}$ on insect vectors of tropical areas. More fungal pathogens were investigated under elevated $\mathrm{CO}_{2}$ levels compared to viral and bacterial pathogens. There is also need to determine the combined influence of carbon dioxide and temperature in a tropical setting so as to come up with a more realistic assessment of the influence of changing climate variables.

\section{Effect of Extreme Weather Events on Insect Pests and Diseases}

Climate change studies project a change in the frequency of extreme weather events such as floods, storms, heat waves and heavy winds (Easterling et al., 2000). These extreme weather events may eliminate vulnerable insect pest stages (egg, larval and pupal stages), leading to breakdown of natural control. Natural control will be disrupted because many parasites and parasitoids will fail to find a host of a suitable or susceptible developmental stage (Cork et al., 2014). The extreme weather events would, therefore, limit reproductive success of the majority of the insects as their early stages become vulnerable to the devastating effect of the extreme weather events. Increases in occurrence and severity of windy periods could also result in the increase in the rate of spread of insects from one area to the other. For example, New Zealand has been exposed to airborne insect pests from Australia for millions of years as a result of heavy winds (Cork et al., 2014).

Excessive rains resulting in flooding cause increases in water-borne transport of pathogens. This increases survival, dissemination and spread of mainly the soil borne pathogens to areas that were not previously infected (Thompson et al., 2013). Fungal pathogens benefit from flood events compared to any other pathogens (Parvatha, 2015). In China, wheat stripe rust outbreak following floods, contributed to the 1960s famine (Rosenzweig et al., 2000). In the United States (U.S.) Great Plains in 1993, mycotoxin produced by wheat scab (Fusarium spp.) reached the highest record after torrential rainfall and continuous soil saturation which caused long-term problems related to root rots (Rosenzweig et al., 2000). In a related rainfall simulation experiment in the UK, the seedlings of the canopy tree, Pleradenophora longicuspis (Standl.) Esser (Euphorbiaceae), were exposed to a gradient of watering volumes at three different frequencies, to test the hypothesis that mortality driven by fungal pathogens increases with both volume and frequency of watering. The results of the experiment revealed that both watering frequency and volume were important determinants of pathogen-induced seedling mortality. Mortality was greatest with heavy and more frequent watering, and declined significantly with less frequent watering (Swinfield et al., 2012). This implies that flood events can enhance the development of fungal pathogens and hence plant mortality resulting from fungal pathogens attack while the development of fungal pathogens can correspondingly decrease with reduced rainfall quantities.

Heavy wind currents provide large scale transportation of disease agents (spores of fungi) from overwintering areas to distant hosts (Rieux et al., 2014). The rain-splashed, polycyclic foliar fungal disease, septoria leaf blotch (Mycosphaerella graminicola) is exacerbated by windy conditions in the United Kingdom (UK). Septoria leaf blotch epidemics are started by air-dispersed ascospores (sexually-produced spores) in late summer and autumn followed by many cycles of rain-splashed conidia (asexually-produced spores) and a second batch of ascospores in spring (West et al., 2015).

Extremely windy conditions accompanied by excessive rainfall are, therefore, likely to result in distant spread of plant pathogens and insect pests that are dispersed by wind and water currents. In addition, extremely wet conditions resulting from heavy rainfall promotes the germination of spores and the proliferation of bacterial and fungal diseases within the crop canopies.

\section{Conclusion}

Elevated temperatures, $\mathrm{CO}_{2}$ and extreme weather events such as floods and storms have an effect on fecundity, development, survival, distribution as well as incidence of insect pests and diseases in a changing climate. Despite an expected increase in insects and diseases, some temperate insect pests as well as some diseases such as wheat stripe rust are expected to become less prevalent under a future climate in the temperate regions. Most research on climate change was mainly conducted in Asian, European and Australian environments and limited information is available on the influence of climate change on polyphagous insects that are dominant in Africa. Future research should focus on the interaction between temperature and $\mathrm{CO}_{2}$ on pests and viral diseases that are prevalent in the warmer tropical areas such as southern Africa. Long term surveillance and monitoring of insect pests is also of importance in climate change studies as this would provide a more realistic assessment of climate change on insect pests and pathogen interaction. Precipitation should also be considered in climate change studies as this is likely to directly and indirectly affect the distribution of tropical insect pest species.

Various models have been used to predict how global warming will affect insect ecosystems. Some of these models have been used to predict the response of individual insect pests to climate change. Future research 
should concentrate on models which are used to explore the response to climate change of various insects and pathogens. Focus should be on modelling insects climate change envelopes along with climate change. This would increase the capacity to forecast insect population.

Risk and hazard rating systems are essential components of crop health management strategy and should be in place and applied in advance of insect epidemics and outbreaks. These systems should be a priority for crop health research and development efforts. In addition climate mapping which predicts the potential distribution on insects in new areas under future climates should be part of the research to support the modelling exercises.

National and regional early warning and surveillance systems should be part of policy to deal with increased pests and diseases under climate change. Most of the work on pests and diseases under climate change has been done in cooler and developed regions. There is need for urgent research in the tropics particularly sub-Saharan Africa which is characterised by low adaptive capacity to deal with the changing climate. These studies should be conducted on pests and diseases on a crop-forestry-livestock-human continuum.

\section{References}

Abolmaaty, S. M., Maklad, A. M., \& Khalil, A. A. (2011). Using degree-day unit accumulation to predict potato tubeworm incidence under climate change conditions in Egypt. Nature and Science, 9(4), 156-160. https://doi.org/10.7537/marsnsj090411.22

African Ministerial Conference on the Environment (AMCEN). (2011). Addressing climate change challenges in Africa: A practical guide towards sustainable development. Nairobi: AMCEN Secretariat. Retrieved from http://www.unep.org/roa/amcen/docs/publications/guidebook

Ahanger, R. A., Bhat, H. A., Bhat, T. A., Ganie, S. A., Lone, A. A., Wani, I. A., Bhat, T. A. (2013). Impact of Climate Change on Plant Diseases. International Journal of Modern Plant and Animal Sciences, 1(3), 105-115.

Altermatt, F. (2012). Temperature related shifts in butterfly phenology depend on the habitat. Global Change Biology, 18, 2429-2438. https://doi.org/10.1111/j.1365-2486.2012.02727.x

Anderson, P. K., Cunningham, A. A., Patel, N. G., Morales, F. J., Epstein, P. R., \& Daszok, P. (2004). Emerging infectious diseases of plants: Pathogen pollution, climate change and agrotechnology drivers. Trends in Ecology and Evolution, 19(10), 535-544. https://doi.org/10.1016/j.tree.2004.07.021

Burrows, M. T., Schoeman, D. S., Richardson, A. J., Molinos, J. G., Hoffmann, A., Buckley, L. B., ... Poloczanska, E. S. (2014). Geographical limits to species-range shifts are suggested by climate velocity. Nature, 507, 492-495. https://doi.org/10.1038/nature12976

Chakraborty, S., Luck, J., Hollaway, G., \& Karnosky, D. F. (2008). Impacts of global change on diseases of agricultural crops and forest trees. CAB Reviews: Perspectives in Agriculture, Veterinary Science. Nutrition and Natural Resources, 3, 1-15. https://doi.org/10.1079/pavsnnr20083054

Chakraborty, S., \& Newton, A. C. (2011). Climate change, plant diseases and food security: An overview. Plant Pathology, 60, 2-14. https://doi.org/10.1111/j.1365-3059.2010.02411.x

Chakraborty, S. (2013). Migrate or evolve: Options for plant pathogens under climate change. Global Change Biology, 19, 1985-2000. https://doi.org/10.1111/gcb.12205

Cork, S., Alford, K., Finnigan, J., Nicky, G., Beth, F., \& Michael, R. (2014). The Challenges of Living Scenarios for Australia in 2050. Journal of Futures Studies, 18(3), 115-126.

Dobson, A. (2009). Climate variability, global change, immunity, and the dynamics of infectious diseases. Ecology, 90, 920-927. https://doi.org/10.1890/08-0736.1

Eastburn, D., Degennaro, M., Delucia, E., Dermody, O., \& McElrone, A. (2010). Elevated atmospheric carbon dioxide and ozone alter soybean diseases at Soy FACE. Global Change Biology, 16, 320-30. https://doi.org/10.1111/j.1365-3059.2010.02402.x

Easterling, D. R., Meehl, G. A., Parmesan, C., Changnon, S. A., Karl, T. R., \& Mearns, L. O. (2000). Climate extremes: Observations, modelling, and impact. Science, 289, 2068-2074. https://doi.org/10.1126/science. 289.5487.2068

Fand, B., Kamble, A. L., \& Kumar, M. (2012). Will climate change pose serious threat to crop pest management: A critical review? International Journal of Scientific and Research, 2(11), 1-13. 
Flower, C. E., Long, L. C., Knight, K. S., Rebbeck, J., Brown, J. S., Gonzalez-Melera, M. A., \& Wheland, C. J. (2014). Native bark-foraging birds preferentially forage in infected ash (Fraxinus spp.) and prove effective predators of the invasive emerald ash borer (Agrilus planipennis Fairmaire). Forest Ecology and Management, 6, 300-313. https://doi.org/10.1016/j.foreco.2013.11.030

Furher, J. (2003). Agroecosystem responses to combinations of elevated carbon dioxide, ozone and global climate change. Agriculture Ecosystems and the Environment, 97, 1-20. https://doi.org/10.1016/S0167-8809 (03)00125-7

Furstenberg-Hagg, J., Zagrobelny, M., \& Bak, S. (2013). Plant defense against insect herbivores. International Journal of Molecular Sciences, 14, 10242-10297. https://doi.org/10.3390/ijms 140510242

Gregory, P. J., Johnson, S. N., Newton, A. C., \& Ingram, J. S. I. (2009). Integrating pests and pathogens into the climate change/food security debate. Journal of Experimental Botany, 60, 2827-2838. https://doi.org/ $10.1093 / \mathrm{jxb} / \mathrm{erp} 080$

Harrison, J. G. (1992). Effects of the aerial environment on late blight of potato foliage-A review. Plant Pathology, 41, 384-416. https://doi.org/10.1111/j.1365-3059.1992.tb02435.x

Hughes, L., \& Bazzazez, F. A. (2001). Effects of elevated $\mathrm{CO}_{2}$ of five plant aphid interactions. Entomologia Experimentalis et Applicata, 99, 87-96. https://doi.org/10.1046/j.1570-7458.2001.00805.x

Intergovernmental Panel on Climate Change (IPCC). (2007). Climate Change: Synthesis Report. Contributions of Working Groups I, II and III to the Fourth Assessment Report of the Intergovernmental Panel on Climate Change. IPCC, Geneva.

Intergovernmental Panel on Climate Change (IPCC). (2013). Working group III, Mitigation of Climate Change (Chapter 1, pp. 3-4). IPCC, Geneva.

Jamieson, M. A., Trowbridge, A. M., Raffa, K. F., \& Lindroth, R. L. (2012). Consequences of climate warming and altered precipitation patterns for plant-insect multitrophic interactions. Plant Physiology, 160(4), 1719-1727. https://doi.org/10.1104/pp.112.206524

Jaramillo, J., Muchugu, E., Vega, F. E., Davis, A., Borgemeister, C., \& Chabi-Olaye, A. (2011). Some Like It Hot: The Influence and Implications of Climate Change on Coffee Berry Borer (Hypothenemus hampei) and Coffee Production in East Africa. PLoS ONE, 6(9), e24528. https://oi.org/10.1371/journal.pone.0024528

Jaramillo, J., Chabi-Olaye, A., Kamonjo, C., Jaramillo, A., Vega, F. E., Poehling, H. M., \& Borgemeister, C. (2009). Thermal tolerance of the coffee berry borer (Hypothenemus Hamperi). Prediction of climate change on a tropical insect pest. PLoS ONE, 4(8), e6487. https://doi.org/10.1371/journal.pone.0006487

Jaworski, T., \& Hilszczanski, J. (2013). The effect of temperature and humidity changes on insect development and their impact on forest ecosystems in the context of expected climate change. Forest Research Papers, 74(4), 345-355. https://doi.org/10.2478/frp-2013-0033

Jennings, P., Coates, M. E., Walsh, K., Turner, J. A., \& Nicholson, P. (2004). Determination of deoxynivalenol-and nivalenol-producing chemotypes of Fusarium graminearum isolated from wheat crops in England and Wales. Plant Pathology, 53, 643-52. https://doi.org/10.1111/j.0032-0862.2004.01061.x

Johnson, S. N., Mitchell, C., Thompson, J., \& Karley, A. J. (2013). Downstairs drivers-root herbivores shape communities of aboveground herbivores and natural enemies via plant nutrients. Journal of Animal Ecology, 82(5), 1021-1030. https://doi.org/10.1111/1365-2656.12070

Karolewski, P., Grzebyta, J., Oleksyn, J., \& Giertych, M. J. (2007). Effects of temperature on larval survival rate and duration of development of Lymantria monacha (L.) on needles of Pinus silvestris (L.) and of L. dispar (L.) on leaves of Quercus robur (L.). Polish Journal of Ecology, 55(3), 595-600.

Karowe, D. N., \& Migliaccio, A. (2011). Performance of the legume-feeding herbivore, Colias philodice (Lepidoptera: Pieridae) is not affected by elevated $\mathrm{CO}_{2}$. Athropod Plant Interactions, 5(2), $107-114$. https://doi.org/10.1007/s11829-010-9119-y

Khaliq, I., Hof, C., Prinzinger, R., Böhning-Gaese, K., \& Pfenninger, M. (2014). Global variation in thermal tolerances and vulnerability of endotherms to climate change. Proceedings of the Royal Society for Biological Sciences, 281, 20141097. https://doi.org/10.1098/rspb.2014.1097

Kroschel, J., Sporleder, J., Tonnang, H. E. Z., Juarez, H., Carhuapoma, J. C., \& Simon, R. (2013). Predicting climate change-caused changes in global temperature on potato tuber moth Phthorimaea operculella (Zeller) 
distribution and abundance using phenology modeling and GIS mapping. Agricultural and Forest Meteorology, 170, 228-241. https://doi.org/10.1016/j.agrformet.2012.06.017

Kutywayo, D., Chemura, A., Kusena, W., Chidoko, P., \& Mahoya, C. (2013). The Impact of Climate Change on the Potential Distribution of Agricultural Pests: The Case of the Coffee White Stem Borer (Monochamus leuconotus P.) in Zimbabwe. PLoS ONE, 8(8), e73432. https://doi.org/10.1371/journal.pone.0073432

Luck, J., Spackman, M., Freeman, A., Trebicki, P., Griffiths, W., Finlay, K., \& Chakraborty, S. (2011). Climate change and diseases of food crops. Plant Pathology, 60, 113-121. https://doi.org/10.1111/j.1365-3059. 2010.02414.x

Ma, G., \& Ma, C. S. (2012a). Effect of acclimation on heat-escape temperatures of two aphid species: Implications for estimating behavioural response of insects to climate warming. Journal of Insect Physiology, 58, 303-309. https://doi.org/10.1016/j.jinsphys.2011.09.003

Ma, G., \& Ma, C. S. (2012b). Climate warming may increase aphids dropping probabilities in response to high temperature. Journal of Insect Physiology, 58, 1456-1462. https://doi.org/10.1016/j.jinsphys.2012.08.012

Mearns, L. O., Sain, S., Leung, L. R., Bukovsky, M. S., McGinnis, S., Biner, S., ... Sloan, L. (2013). Climate change projections of the North American Regional Climate Change Assessment Program (NARCCAP). Climate Change, 120, 965-75. https://doi.org/10.1007/s10584-013-0831-3

Miedaner, T., Cumagun, C. J. R., \& Chakraborty, S. (2008). Population genetics of three important head blight pathogens Fusarium graminearum, F. pseudograminearum and F. culmorum. Journal of Phytopathology, 156, 129-139. https://doi.org/10.1111/j.1439-0434.2007.01394.x

Miller-Rushing, A., Hoye, T., Inouye, D., \& Post, E. (2010). The effects of phonological mismatches on demography. Philosophical Transactions of the Royal Society, 365, 3177-3186. https://doi.org/10.1098/rstb. 2010.0148

Mirski, T., Bartoszcze, M., \& Bielawska-Drozd, A. (2012). Impact of climate change on infectious diseases. Polish Journal of Environmental Studies, 21(3), 525-532.

Mitrovski, P., Hoffmann, A. A., Heinze, D, A., \& Weeks, A. R. (2008). Rapid loss of genetic variation in an endangered possum. Biology Letters, 4, 134-138. https://doi.org/10.1098/rsbl.2007.0454

Moyo, M., Mvumi, B. M., Kunzekweguta, M., Mazvimavi, K., Craufurd, P., \& Dorward, P. (2012). Farmer perceptions on climate change and variability in semi-arid Zimbabwe in relation to climatology evidence. African Crop Science Journal, 20(2), 317-335.

Newton, A. C., Johnson, S. N., \& Gregory, P. J. (2011). Implication of climate change for diseases crop yields and food security. Euphytica, 179, 3-18. https://doi.org/10.1007/s10681-011-0359-4

Nissen, K. M., Leckebusch, G. C., Pinto, J. G., \& Ulbrich, U. (2014). Mediterranean cyclones and windstorms in a changing climate. Regional Environmental Change, 14, 1873-1890. https://doi.org/10.1007/s10113-0120400-8

Nurhayati, D. (2013). The effects of climate change on plant diseases and possible means for their mitigation. Proceeding of 2013 International Seminar on Climate Change and Food Security (ISCCFS 2013) Palembang, South Sumatra-Indonesia, 24-25 October, 2013.

Parvatha, R. P. (2015). Climate resilient agriculture for ensuring food security. New Dehli, Springer.

Perkins, L. B., Leger, E. A., \& Nowak, R. S. (2011). Invasion triangle: A framework for species invasion. Ecology \& Evolution, 1, 610-625. https://doi.org/10.1002/ece3.47

Petzoldt, C., \& Seaman, A. (2010). Climate Change Effects on Insects and Pathogens. Climate change and agriculture: Promoting practical and profitable responses (p. 616). Retrieved from http://www.climateandfarming.org/pdfs/FactSheets/III.2Insects.Pathogens.pdf

Piyaphongkul, J., Pritchard, J., \& Bale, J. (2012). Can Tropical Insects Stand the Heat? A Case Study with the Brown Plant hopper (Nilaparvata lugens) (Sta 1). PLoS ONE, 7(1), e29409. https://doi.org/10.1371/ journal.pone.0029409

Rieux, A., Soubeyrand, S., Bonnot, F., Klein, E. K., Ngando, J. E., Mehl, A., ... Bellaire, L. L. (2014). Long-Distance Wind-Dispersal of Spores in a Fungal Plant Pathogen: Estimation of Anisotropic Dispersal Kernels from an Extensive Field Experiment. PLoS ONE, 9(8), e103225. https://doi.org/10.1371/journal. pone. 0103225 
Sanderson, B. M., O’neill, B. C., Kiehl, J. T., Meehl, G. A., Knutti, R., \& Washington, W. M. (2011). The response of the climate system to very high greenhouse gas emission scenarios. Environmental Research Letters, 6, 034005. https://doi.org/10.1088/1748-9326/6/3/034005

Seiter, S., \& Kingsolver, J. (2013). Environmental determinants of population divergence in life-history traits for an invasive species: Climate, seasonality and natural enemies. Journal of Evolutionary Biology, 26, 1634-1645. https://doi.org/10.1111/jeb.12159

Selvaraj, G., \& Pandiara, T. (2013). Potential impacts of recent climate change on biological control agents in agro-ecosystem: A review. International Journal of Biodiversity and Conservation, 5(12), 845-852. https://doi.org/10.5897/IJBC2013.0551

Sharma, S., Magnuson, J. J., Mendoza, G., \& Carpenter, S. R. (2013). Influences of local weather, large-scale climatic drivers, and the solar cycle on ice breakup dates; 1905-2004. Climatic Change, 118, 857-870. https://doi.org/10.1007/s10584-012-0670-7

Sharma, H. C., Srivastava, C. P., Durairaj, C., \& Gowda, C. L. L. (2010). Pest management in grain legumes and climate change. In S. S. Yadav, D. L. McNeil, R. Redden, \& S. A. Patil, (Eds.), Climate Change and Management of Cool Season Grain Legume Crops (pp. 115-140). Dordrecht, The Netherlands: Springer Science + Business Media. https://doi.org/10.1007/978-90-481-3709-1_7

Shi, B., Huang, J., Hu, C., \& Hou, M. (2014). Interactive effects of elevated $\mathrm{CO}_{2}$ and temperature on rice plant hopper (Nilaparvata lugens). Journal of Integrative Agriculture, 13(7), 1520-1529. https://doi.org/10.1016/ S2095-3119(14)60804-2

Swinfield, T., Owen, T., Lewis, O. T., Bagchi, R., \& Freckleton, R. P. (2012). Consequences of changing rainfall for fungal pathogen-induced mortality in tropical tree seedlings. Ecology and Evolution, 2(7), 1408-1413. https://doi.org/10.1002/ece3.252

Terblanche, J. S., Clusella-Trullas, S., Deer, J. A., \& Chown, S. L. (2008). Thermal tolerance in a South-East African population if the tse-tse fly Glossina pallidipes (Diptera, Glossinidae): Implications for forecasting climate change impacts. Journal of Insect Physiology, 54, 114-127. https://doi.org/10.1016/j.jinsphys.2007. 08.2007

Thompson, H. F., Berrang-Ford, L., \& Ford, J. P. (2010). Climate change and food security in SSA: A systematic literature review. Sustainability, 2, 2719-2733. https://doi.org/10.3390/su2082719

Waalwijk, C., Kastelein, P., de Vries, I., Kerényi, Z., van der Lee, T., Hesselink, T., ... Kema, G. (2003). Major changes in Fusarium spp. in wheat in the Netherlands. European Journal of Plant Pathology, 109, $743-54$. https://doi.org/10.1023/A:1026086510156

Watson, R. T. (2001). Climate Change 2001: Synthesis Report. A Contribution of Working Groups I, II, and III to the Third Assessment Report of the Intergovernmental Panel on Climate Change. Cambridge, UK: Cambridge.

West, J. S., Fitt, B. D. L., Townsend, J. A., Stevens, M., Edwards, S. G., Turner, J. A., ... Edmonds, J. (2015). Impact of climate change on diseases on sustainable crop systems: CLIMDIS. Project Number 539. HCGA.

William, A. P., Seager, R., Abatzoglu, J. T., Cook, B. I., Smerdon, J. E., \& Cook, E. R. (2015). Contribution of anthropogenic warming to California drought during 2012-2014. Geophysical Research Letters, 42, 6819-6828. https://doi.org/10.1002/2015GL064924

Yamamura, K., \& Kiritani, K. (1998). A simple method to estimate the potential increase in the number of generations under global warming in temperate zones. Applied Entomology and Zoology, 33, $289-298$. https://doi.org/10.1303/aez.33.289

Zeh, J. A., Bonilla, M. M., Su, E. J., Padua, M. V., Anderson, R. V., Kaur, D., ... Zeh, D. W. (2012). Degrees of disruption: projected temperature increase has catastrophic consequences for reproduction in a tropical ectotherm. Global Change Biology, 18(6), 1833-1842. https://doi.org/10.1038/srep00375

\section{Copyrights}

Copyright for this article is retained by the author(s), with first publication rights granted to the journal.

This is an open-access article distributed under the terms and conditions of the Creative Commons Attribution license (http://creativecommons.org/licenses/by/4.0/). 